University of Nebraska - Lincoln

DigitalCommons@University of Nebraska - Lincoln

Nebraska Cooperative Fish \& Wildlife Research Nebraska Cooperative Fish \& Wildlife Research Unit -- Staff Publications

2011

\title{
Luring anglers to enhance fisheries
}

D. R. Martin

University of Nebraska-Lincoln, dustin.martin@huskers.unl.edu

Kevin L. Pope

University of Nebraska-Lincoln, kpope2@unl.edu

Follow this and additional works at: https://digitalcommons.unl.edu/ncfwrustaff

Part of the Other Environmental Sciences Commons

Martin, D. R. and Pope, Kevin L., "Luring anglers to enhance fisheries" (2011). Nebraska Cooperative Fish \& Wildlife Research Unit -- Staff Publications. 82.

https://digitalcommons.unl.edu/ncfwrustaff/82

This Article is brought to you for free and open access by the Nebraska Cooperative Fish \& Wildlife Research Unit at DigitalCommons@University of Nebraska - Lincoln. It has been accepted for inclusion in Nebraska Cooperative Fish \& Wildlife Research Unit -- Staff Publications by an authorized administrator of DigitalCommons@University of Nebraska - Lincoln. 


\title{
Luring anglers to enhance fisheries
}

\author{
Dustin R. Martin ${ }^{\mathrm{a}, \mathrm{c}, *}$, Kevin L. Pope ${ }^{\mathrm{b}, \mathrm{c}}$ \\ ${ }^{a}$ Nebraska Cooperative Fish and Wildlife Research Unit, University of Nebraska, Lincoln, NE 68583, USA \\ ${ }^{\mathrm{b}}$ U.S. Geological Survey-Nebraska Cooperative Fish and Wildlife Research Unit, University of Nebraska, Lincoln, NE 68583, USA \\ ${ }^{\mathrm{c}}$ School of Natural Resources, University of Nebraska, Lincoln, NE 68583, USA
}

\section{A R T I C L E I N F O}

\section{Article history:}

Received 2 September 2010

Accepted 4 October 2010

Available online 20 October 2010

\section{Keywords:}

Adaptive management

Angler participation

Managing anglers

Regional-fishery management

\begin{abstract}
A B S T R A C T
Current fisheries management is, unfortunately, reactive rather than proactive to changes in fishery characteristics. Furthermore, anglers do not act independently on waterbodies, and thus, fisheries are complex socio-ecological systems. Proactive management of these complex systems necessitates an approach-adaptive fisheries management-that allows learning to occur simultaneously with management. A promising area for implementation of adaptive fisheries management is the study of luring anglers to or from specific waterbodies to meet management goals. Purposeful manipulation of anglers, and its associated field of study, is nonexistent in past management. Evaluation of different management practices (i.e., hypotheses) through an iterative adaptive management process should include both a biological and sociological survey to address changes in fish populations and changes in angler satisfaction related to changes in management. We believe adaptive management is ideal for development and assessment of management strategies targeted at angler participation. Moreover these concepts and understandings should be applicable to other natural resource users such as hunters and hikers.
\end{abstract}

(ㄷ) 2010 Elsevier Ltd. All rights reserved.

\section{Introduction}

Adaptive management is an iterative process in which management actions are implemented in such a manner to test competing conceptual models of a system or to test specific components of a working conceptual model. Current fisheries management is, unfortunately, reactive rather than proactive to changes in fishery characteristics. Furthermore, external pressures, such as anglers and global climate change, do not act independently on waterbodies, and thus, fisheries are complex socio-ecological systems. Proactive management of these complex systems necessitates an approach-adaptive fisheries management-that allows learning to occur simultaneously with management. Adaptive fisheries management must incorporate socio-economic and biological monitoring to better understand and manage multiple waterbodies within a region. Management of individual waterbodies in traditional ways is still important; however, management objectives of an individual waterbody should be defined within the context of a watershed or region. In this paper, we develop an

\footnotetext{
* Corresponding author. Nebraska Cooperative Fish and Wildlife Research Unit, University of Nebraska, 013 Hardin Hall, Lincoln, NE 68583, USA. Tel.: +1 402472 9126; fax: +1 4024722722 .

E-mail addresses: dustin.martin@huskers.unl.edu (D.R. Martin), kpope2@unl. edu (K.L. Pope).
}

adaptive management strategy for managing waterbodies within a regional fishery.

\section{History of fishery management}

In the United States of America, fisheries management began as a reaction to the reduction or even extirpation of exploited fish populations (Nielsen, 1993), and as with the management of any renewable natural resource, fisheries management has and continues to focus on ensuring resource sustainability. Historically, this was achieved through the direct manipulation of fish populations, via hatchery-stock replenishment programs and harvest management, with the expressed purpose of achieving maximum sustainable yield (Russell, 1942). Maximum sustainable yield assumes populations follow a logistic growth model and thereby aims to maintain a population at the point of maximum growth rate through harvest quotas (Schaefer, 1954). Although, it is possible to manage for maximum sustainable yield (e.g., limited-access fisheries; Hilborn et al., 2005) it is difficult to manage fisheries successfully following this paradigm if fisheries are open-access (Rosenberg et al., 1993), or if fishing pressure forces short harvest seasons (e.g., Pacific halibut (Hippoglossus stenolepis Schmidt) fishery; Gates, 2005). Moreover, maximum sustainable yield focuses solely on biomass production, but it has become increasingly apparent that sociological values, along with economic values, placed on fishing 
contribute to the overall value derived from fishing (McFadden, 1969) and that single-species management is less than desirable because fish populations are interdependent (Zabel et al., 2003). These concerns led to the development of optimum sustainable yield (Roedel, 1975), which differs from maximum sustainable yield in that management actions no longer focus solely on maximizing harvest; social, economic, and biological sustainability are as important as maximizing harvest. Human use and values thus play an integral part in the formulation of management actions, especially regulations, and require management agencies to conduct socio-economic studies and angler surveys to identify interests of their constituents (Wilde et al., 1996).

Though the current focus of fisheries management is waterbody-specific regulations for fishing, there is a growing realization that watershed-level issues affect each waterbody (Lester et al., 2003) and that mobility of anglers influences each waterbody within a region (Carpenter and Brock, 2004). Socio-ecological models have shown that these large-scale relationships are diverse and complicated (Carpenter and Brock, 2004), and that a singlefocus management approach leads to greater variability in fish-population response than does a proactive experimental management approach (i.e., adaptive management; Carpenter and Gunderson, 2001).

\section{Conceptual model of a fishery}

Generally, a fishery is defined as "a system that includes target organisms, the habitat in which they exist, the community of species in which the target organisms live, and the humans who exploit or affect the target species" (Murphy and Willis, 1996). This one-waterbody system is often depicted as three overlapping circles (Nielsen, 1993) that represent habitat, organisms and human users (Fig. 1A). However, given what we currently know about fisheries management, we propose a revision to the conceptual fishery model that emphasizes the human component over the fish and habitat components. This revision does not alter the role of anglers within a fishery, but rather reflects our growing enlightenment about the importance of anglers, politics and economics. This conceptualization is illustrated with a rearrangement of the circles representing habitats, organisms and society (Fig. 1B). We explicitly acknowledge that humans (anglers and non-anglers) are highly mobile and can travel to any waterbody (e.g., lake or reservoir) within a region; thus, humans have the ability to influence fish communities of any waterbody within that region. Furthermore, every waterbody has the capacity to influence human behavior by drawing anglers from nearby waterbodies.

This relationship between waterbodies within a region and the sociological aspects of human behavior and mobility suggest that "regional-fishery management" is a more appropriate term than fisheries management; regional-fishery management is defined as managing individual waterbodies in the context of all other regional waterbodies. We contend that managers must consider potential positive and negative effects on associated waterbodies when setting regulations or conducting other management activities for a given waterbody. Within the context of the regionalfishery model, we further refine our conceptual model of a fishery by acknowledging that participation patterns and behavior likely vary among angler groups within the regional-fishery (Fig. 1C). Furthermore, the region of interest within this model is not limited to one watershed; anglers have the ability to travel to many watersheds for angling. This conceptual model allows for a broader interpretation of a fishery and allows for the creation of multiple hypotheses to test using adaptive management.

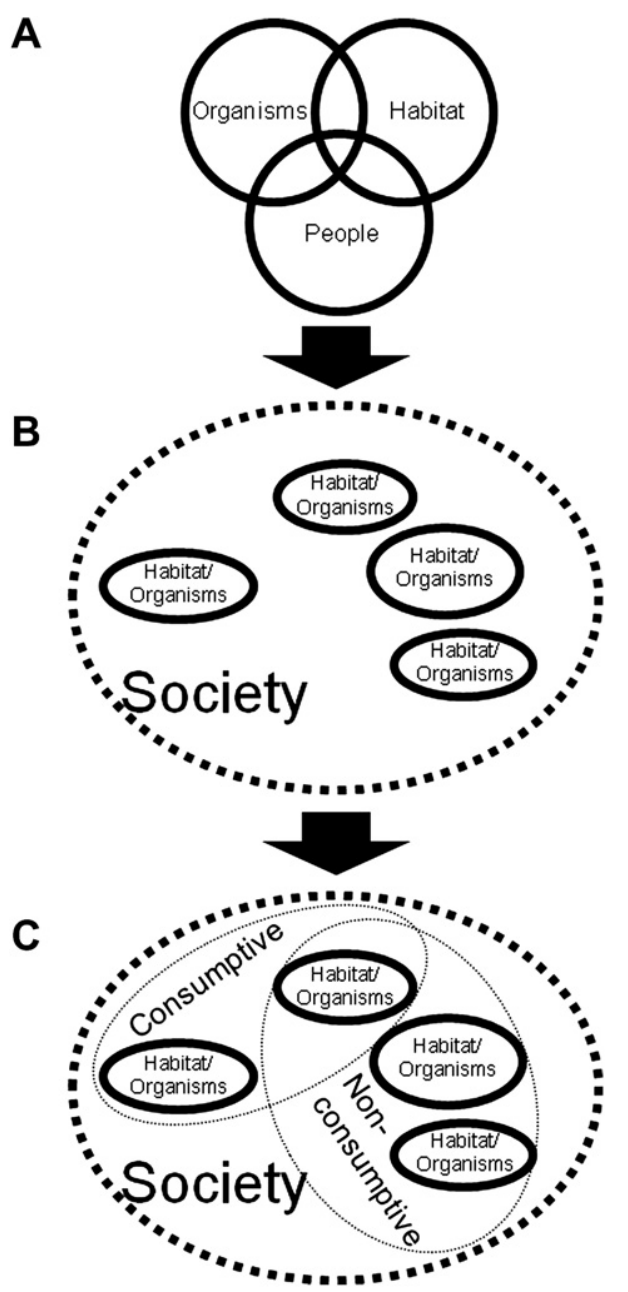

Fig. 1. Evolution of the model illustrating a fishery. Conceptual model A illustrates the three components of a fishery as overlapping rings (altered from Nielsen, 1993). This is the standard model that has been taught to undergraduate students for the past two decades. Conceptual model B illustrates the connectedness of regional waterbodies via angler mobility. This model builds on the traditional model A with two important distinctions: this new model recognizes that 1) organisms do not exist outside of habitat (i.e., ring denoting organisms is confined for each waterbody by ring denoting habitat) and 2) every waterbody competes for anglers (i.e., anglers make choices about where they will fish on any given day). Conceptual model C illustrates some of the complexity of a regional fishery with recognition of multiple angler groups (e.g. consumption-oriented and nonconsumption-oriented anglers).

\section{Salt Creek watershed: example of a regional fishery}

We develop a scenario in which adaptive management can be used to facilitate the understanding of a complex socio-ecological system (i.e., a regional fishery). The Salt Creek watershed of southeastern Nebraska is a good example of a regional fishery. This watershed contains 19 public reservoirs that range in size from small ponds to large flood-control reservoirs (Fig. 2). The second largest city in Nebraska, Lincoln, is located within this watershed allowing utilization of these reservoirs by greater than 300,000 potential anglers (United States Census Bureau, 2010). Our illustration of regional-fishery management, which involves managing one waterbody within the context of offerings by nearby waterbodies, incorporates the choice that anglers have of where and when to fish. The mobility of anglers to move among waterbodies allows managers the opportunity to influence, whether intentional or not, participation rates at different waterbodies through management actions that entice and repel anglers to a given 


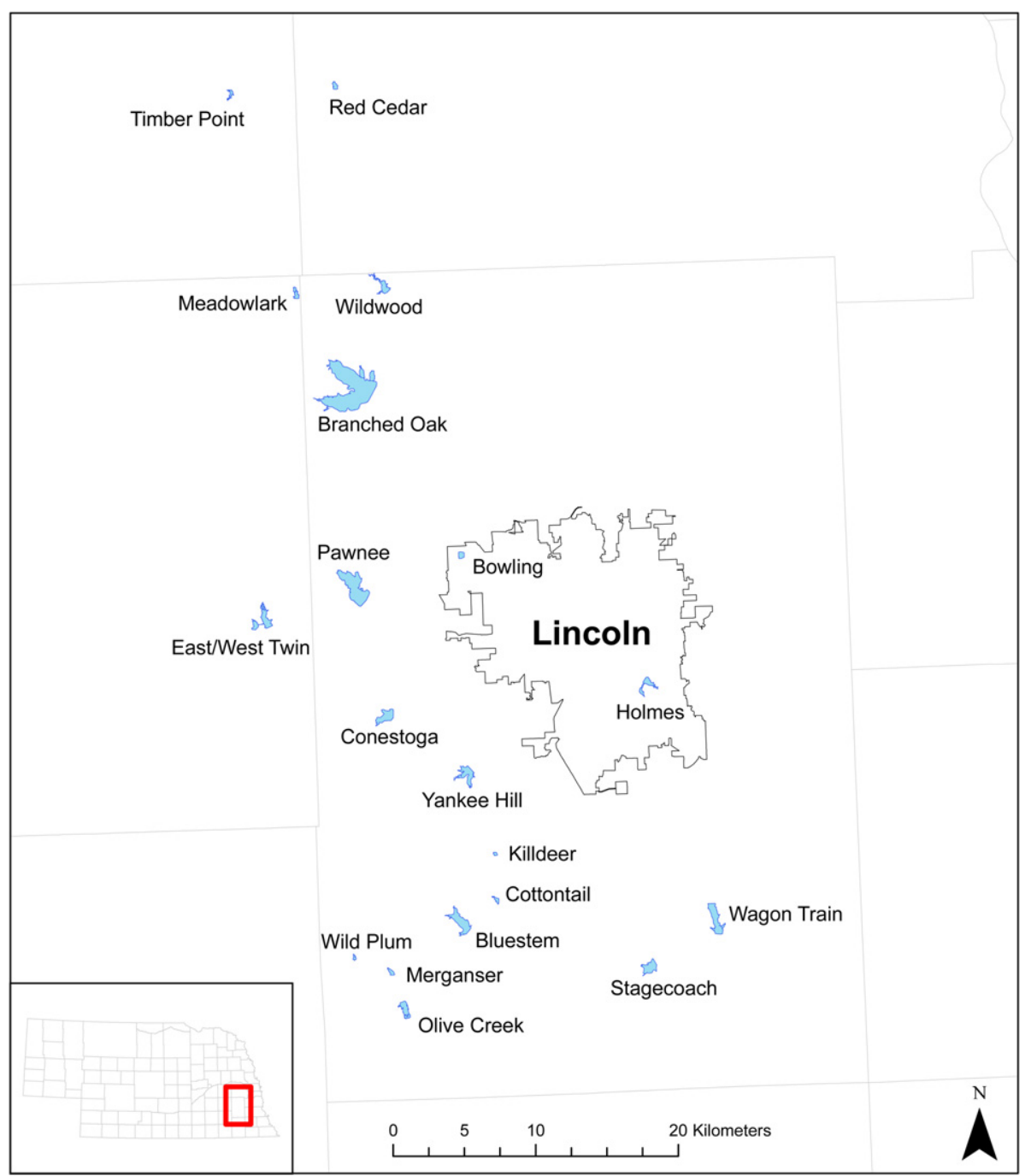

Fig. 2. Map of 19 reservoirs located in the Salt Creek watershed in southeastern Nebraska, USA.

waterbody. Fishing regulations imposed by the Nebraska Game and Parks Commission are currently waterbody-specific on these 19 reservoirs.

\subsection{Substitute waterbodies}

Choice of waterbody by anglers is driven by a combination of six factors: travel cost, fishing quality, environmental quality, facility development, encounter rate with other anglers, and regulations in place (Hunt, 2005). These factors combine to form a ranking of waterbodies for each individual angler that serves as their set of substitute waterbodies. This listing of sites along with the dynamics of daily fishing conditions leads to variation in where an angler chooses to fish on any given day.

There are two competing hypotheses that provide insight to an angler's choice to fish on a given day at a given waterbody. The first hypothesis states that an angler will choose not to fish, but rather participate in another substitute activity, if they are unable to access a preferred waterbody. The second hypothesis states that an angler will choose another substitute waterbody to fish if they are unable to access their preferred waterbody.

Adaptive management provides a framework for learning from these competing hypotheses because they are mutually exclusive on an individual basis, but not on a population basis. Planning and carrying out hypothesis testing in conjunction with future waterbody closures, or perceived closures (e.g., harmful-algal blooms) through an iterative adaptive management process, in the Salt Creek watershed are needed to identify the main factors that anglers use to decide where and when to fish. These factors can then be used to manage other reservoirs within the Salt Creek watershed. For example, preliminary results from ongoing inperson surveys at reservoirs within the Salt Creek watershed indicate that anglers at urban reservoirs are more likely to substitute angling activity with other recreational and non-recreational activities on a given day if they do not have access to their preferred reservoir than are anglers at rural reservoirs. Forty-five percent of anglers at Holmes Reservoir, a 40-ha reservoir within Lincoln city limits, indicated they would not have fished the day they were interviewed if Holmes Reservoir had been closed to fishing, 15\% of anglers indicated they would have fished at a substitute waterbody outside this watershed, and $40 \%$ of anglers indicated they would have fished at a substitute waterbody within this watershed. In contrast, $4 \%$ of anglers at Stagecoach Reservoir, a 79-ha reservoir outside Lincoln city limits, indicated they would not have fished the day they were interviewed if Stagecoach Reservoir had been closed to fishing, $6 \%$ of anglers indicated they would have fished at 
a substitute waterbody outside this watershed, and $89 \%$ of anglers indicated they would have fished at a substitute waterbody within this watershed. Future renovations and algal outbreaks in the Salt Creek watershed provide unique opportunities to test the two competing hypotheses listed above, and begin to address issues at the angler scale that are necessary for the advancement of fishery management (Johnson and Carpenter, 1994).

\subsection{Secondary substitute waterbodies}

The additional fishing pressure placed on substitute reservoirs resulting from the closure of a preferred reservoir likely increases encounter rates among anglers at the substitute sites. Preliminary information indicates that a closure of Holmes Reservoir would result in a 93\% increase of angling pressure at Bowling Reservoir, the other reservoir within Lincoln city limits, and a 6-31\% increase of angling pressure at eight reservoirs in this watershed outside Lincoln city limits. Though premature to conclude, it is likely that displacement of anglers from Holmes Reservoir to nine other local reservoirs would in turn create a domino effect of angler displacement at these nine reservoirs to other activities and/or additional substitute sites.

\section{Management of anglers within a regional fishery}

Understanding participation patterns and motives of anglers will improve the ability of managers to manipulate (or manage), directly and indirectly, anglers-that is, lure anglers from overutilized waterbodies to underutilized waterbodies. Whether intended or not, all management actions affect participation patterns by anglers, and we contend that it is time for an open and honest dialog about purposeful management of anglers. We further contend that an adaptive management framework is necessary for implementation of purposeful management of anglers so that we can quickly learn the best practices for achieving our desired results.

Let's explore a hypothetical waterbody that is currently receiving more harvest pressure than the fish populations can support and how an adaptive management approach that incorporates social and biological management actions could help facilitate the sustainability of the fishery in that waterbody and the watershed in which it lies. There are a number of management activities that might reduce harvest. First, a manager might begin by restricting fish harvest. Restrictive regulations (e.g., reduced bag limits and increased minimum-length limits) may reduce total harvest (Colvin, 1991) and fishing pressure. Note, however, that even the most restrictive harvest regulations (i.e., catch-andrelease angling only) will not allow fish populations to support an ever-increasing amount of fishing pressure because of hooking mortality (Muoneke and Childress, 1994). Gear regulations, such as restrictions on bait type (Alos et al., 2009) or lure size (Wilde et al., 2003), may reduce overall angling success while increasing the overall size of fish that are caught and likely harvested. Regardless, numbers of harvestable-sized fish caught by anglers generally decreases with more restrictive regulations, which may decrease angler satisfaction (e.g., Oh and Ditton, 2006) and ultimately reduce fishing pressure at the waterbody (Beard et al., 2003).

If restrictive harvest regulations are insufficient to solve the problem on this hypothetical waterbody, managers can directly restrict fishing pressure (Cox et al., 2002). Restricting fishing pressure (e.g., implementing an annual harvest quota or limiting access) might reduce total harvest, thereby allowing fish populations to recover from overexploitation. Reducing total fishing pressure on an overexploited waterbody also decreases incidental hooking mortality (Schroeder and Love, 2002). Quota regulations and access limitations show promise for reducing total fishing pressure; however, they also likely decrease angler satisfaction (Radomski, 2003).

Another management technique that could be used to reduce fishing pressure and harvest on this hypothetical waterbody is to lure anglers to other waterbodies. Relaxing regulations (e.g., increased bag limits and/or reduced minimum length limits) at nearby waterbodies that can support additional pressure may lure anglers away from the overexploited waterbody. Angling pressure would be dispersed across more waterbodies, thereby minimizing user conflicts and increasing angler satisfaction at the hypothetical overexploited waterbody. However, increased angling pressure at nearby waterbodies may create new user conflicts that decrease angler satisfaction. Supplemental stocking of targeted fish species at nearby waterbodies may also lure anglers from the waterbody of concern. For heavily exploited waterbodies (i.e., urban waterbodies like Holmes Reservoir), a combination of relaxing regulations and supplemental stocking may be needed to achieve the management goals of reduced fishing pressure and harvest.

An adaptive management framework would be useful to determine the best management practices to reduce angling pressure on this hypothetical waterbody. If there are multiple waterbodies within a region, these management practices could be implemented simultaneously to determine effects on fish harvest and angling pressure. Another possible framework is to assign different management practices to the same waterbody over a few years to minimize spatial variation. However, results of management practices are not immediate; thus, requiring longer periods for each management practice implementation. Therefore, if multiple waterbodies are available within a small geographic region, we suggest testing different management practices on each waterbody. Evaluation of different management practices (i.e., hypotheses) should include both biological and sociological surveys to address changes in fish populations and angler satisfaction because of management practices.

\section{Adaptive regional-fisheries management strategy}

Luring anglers to or from specific areas is a promising area for implementation of adaptive management, especially for management issues in which harvest-oriented anglers are an important part of the solution. Combining management and research into one objective instead of two facilitates this new approach to management of natural resources (Conroy and Peterson, 2006). For example, there are at least four competing hypotheses concerning participation by anglers among waterbodies: harvest regulations have the greatest influence on angler participation patterns; stocking strategies have the greatest influence on angler participation patterns; characteristics of fish populations/waterbodies have the greatest influence on angler participation patterns; fishing pressure (i.e., perceived angler crowding) has the greatest influence on angler participation patterns. Each competing hypothesis would result in a different pattern of angler participation in response to changes in regulations and stocking strategies.

Managers could establish treatments, such as regulation schemes and stocking schedules that are believed to influence angler participation. Ideally, management actions that are believed to attract and repel anglers would be incorporated within each treatment. For example, monthly stockings of catchable-size channel catfish (Ictalurus punctatus Rafinesque) could be contrasted with no stockings of channel catfish. Similarly, catch-and-release only regulations could be contrasted with current statewide harvest regulations for channel catfish. Purposeful rotation of treatments (regulation schemes and stocking schedules) among waterbodies within a region, such as the 19 Salt Creek reservoirs, 
provides an opportunity to measure the actual response in angler participation to changes in regulation scheme and stocking strategies, and thus, test these four competing hypotheses. Once tested and evaluated, we can then refine our regional model of angler participation.

Another benefit of the proposed adaptive management strategy (iterative approach to implementing harvest regulations and stocking schedules) is the analysis of cascading effects of fishing pressure, specifically the shifting of fishing pressure to substitute waterbodies or the loss of fishing activity to other recreational activities. If primary substitute waterbodies become crowded, fishing pressure is likely to shift to secondary substitute waterbodies. In some cases, cascading fishing pressure may be evenly distributed across all substitute waterbodies, though it is evident that cascading fishing pressure in the Salt Creek reservoirs would be disproportionally distributed to waterbodies that are most similar to the primary waterbody or to other recreational activities. An adaptive management strategy should thus also anticipate and monitor these secondary responses on large temporal and spatial scales.

\section{Conclusion}

The concepts and discussion presented herein provide a framework for learning how to manage recreational participants. Purposeful manipulation of anglers (and its associated field of study) has been nonexistent in past management. We believe adaptive management is ideal for development and assessment of management strategies targeted at angler participation. Further, these concepts and understandings should be applicable to other natural resources users such as hunters and hikers.

\section{Acknowledgements}

We thank Don Gabelhouse, Jr., Jeff Jackson and Brenda Pracheil for helpful comments on earlier drafts of this manuscript. Many of the ideas presented here originated while working on Federal Aid in Sport Fish Restoration project F-182-R, which was administered by the Nebraska Game and Parks Commission. Any use of trade names is for descriptive purposes only and does not imply endorsement by the U.S. Government. The Nebraska Cooperative Fish and Wildlife Research Unit is jointly supported by a cooperative agreement among the U.S. Geological Survey, the Nebraska Game and Parks Commission, the University of Nebraska, the U.S. Fish and Wildlife Service, and the Wildlife Management Institute.

\section{References}

Alos, J., Arlinghaus, R., Palmer, M., March, D., Alvarez, I., 2009. The influence of type of natural bait on fish catches and hooking location in a mixed-species marine recreational fishery, with implications for management. Fisheries Research 97, 270-277.

Beard Jr., T.D., Cox, S.P., Carpenter, S.R., 2003. Impacts of daily bag limit reductions on angler effort in Wisconsin walleye lakes. North American Journal of Fisheries Management 23, 1283-1293.

Carpenter, S.R., Gunderson, L.H., 2001. Coping with collapse: ecological and social dynamics in ecosystem management. BioScience 51, 451-457.

Carpenter, S.R., Brock, W.A., 2004. Spatial complexity, resilience, and policy diversity: fishing on lake-rich landscapes. Ecology and Society 9, 8. http://www. ecologyandsociety.org/vol9/iss1/art8/ [online] URL.

Colvin, M.A., 1991. Evaluation of minimum-size limits and reduced daily limits on the crappie populations and fisheries in five large Missouri reservoirs. North American Journal of Fisheries Management 11, 585-597.

Conroy, M.J., Peterson, J.T., 2006. Integrating management, research, and monitoring: balancing the 3-legged stool. Gamebird 2006, 413-421.

Cox, S.P., Beard, T.D., Walters, C., 2002. Harvest control in open-access sport fisheries: hot rod or asleep at the reel? Bulletin of Marine Science 70, 749-761.

Gates, J.M., 2005. Management of the pacific halibut fishery. In: Cunningham, S., Bostock, T. (Eds.), Successful Fisheries Management: Issues, Case Studies and Perspectives. Eburon Academic Publishers, Netherlands, pp. 45-74.

Hilborn, R., Orensanz, J.M., Parma, A.M., 2005. Institutions, incentives, and the future of fisheries. Philosophical Transactions of the Royal Society B 360, 47-57.

Hunt, L.M., 2005. Recreational fishing site choice models: insights and future opportunities. Human Dimensions of Wildlife 10, 153-172.

Johnson, B.M., Carpenter, S.R., 1994. Functional and numerical responses: a framework for fish-angler interactions. Ecological Applications 4, 808-821.

Lester, N.P., Marshall, T.R., Armstrong, K., Dunlop, W.I., Ritchie, B., 2003. A broadscale approach to management of Ontario's recreational fisheries. North American Journal of Fisheries Management 23, 1312-1328.

McFadden, J.G., 1969. Trends in freshwater sport fisheries of North America. Transactions of the American Fisheries Society 98, 136-150.

Muoneke, M.I., Childress, W.M., 1994. Hooking mortality: a review for recreational fisheries. Reviews in Fisheries Science 2, 123-156.

Murphy, B.R., Willis, D.W., 1996. Fisheries Techniques, second ed. American Fisheries Society, Bethesda, Maryland.

Nielsen, L.A., 1993. History of Inland Fisheries Management in North America. In: Hubert, W.A., Kohler, C.C. (Eds.), Inland Fisheries Management in North America, second ed. American Fisheries Society, Bethesda, Maryland, pp. 3-31.

Oh, C., Ditton, R.B., 2006. Using recreational specialization to understand multiattribute management preferences. Leisure Sciences 28, 369-384.

Radomski, P., 2003. Initial attempts to actively manage recreational fishery harvest in Minnesota. North American Journal of Fisheries Management 23, 1329-1342.

Roedel, P.M., 1975. Optimum sustainable yield as a concept in fisheries management. Special Publication 9. American Fisheries Society, Bethesda, Maryland.

Rosenberg, A.A., Fogarty, M.J., Sissenwine, M.P., Beddington, J.R., Shepard, J.G., 1993. Achieving sustainable use of renewable resources. Science 262, 828-829.

Russell, E.S., 1942. The Overfishing Problem. Cambridge University Press, Cambridge, UK.

Schaefer, M.B., 1954. Some aspects of the dynamics of populations, important for the management of commercial fisheries. Bull. Inter-American Trop. Tuna Commission 1 (2), 27-56.

Schroeder, D.M., Love, M.S., 2002. Recreational fishing and marine fish populations in California. California Cooperative Oceanic Fisheries Investigations Report 43, $182-190$.

United States Census Bureau. 2010. Table 1 Annual estimates of the resident population for counties of Nebraska: April 1, 2000 to July 1, 2009 (CO-EST2009-0131). U.S. Census Bureau, Population Division.

Wilde, G.R., Ditton, R.B., Grimes, S.R., Riechers, R.K., 1996. Status of human dimensions surveys sponsored by state agencies and provincial fisheries management agencies in North America. Fisheries 21, 12-17.

Wilde, G.R., Pope, K.L., Durham, B.W., 2003. Lure-size restrictions in recreational fisheries. Fisheries 28, 18-26.

Zabel, R.W., Harvey, C.J., Katz, S.L., Good, T.P., Levin, P.S., 2003. Ecologically sustainable yield. American Scientist 91, 150-157. 